\title{
Studi Harmonisa Akibat Komponen Penyearah pada Gardu Traksi Kereta Rel Listrik (KRL)
}

\author{
I Made Ardita $\mathrm{Y}^{1}$, Ahmad Zamzami ${ }^{2}$, .Fauzan Hanif Jufri ${ }^{3}$, dan Faiz Husnayain ${ }^{4}$ \\ ${ }_{1,2,3,4}$ Departemen Teknik Elektro, Fakultas Teknik, Universitas Indonesia \\ Electric Power and Energy Studies (EPES), Fakultas Teknik, Universitas Indonesia \\ Jl. Margonda Raya, Depok, Jawa Barat 16424, Indonesia \\ email: faiz.h@ui.ac.id
}

\begin{abstract}
Abstrak - Sistem elektrifikasi pada Kereta Rel Listrik (KRL) Jabodetabek memakai sistem arus searah 1500 VDC. Sistem saluran atas 1.500 VDC disuplai dari gardu traksi yang dilengkapi dengan komponen penyearah silicon rectifier. Komponen penyearah ini dapat menghasilkan harmonisa yang bisa mendistorsi sumber tegangan menengah $20 \mathrm{kV}$ PLN dan dalam jangka panjang dapat menyebabkan rusaknya peralatan listrik. Penelitian ini bertujuan untuk mengetahui nilai tegangan dan arus harmonisa serta merancang filter harmonisa pada gardu traksi KRL. Hasil pengukuran distorsi harmonisa pada kubikel 20kV/1.2kV gardu traksi dengan PQA menunjukkan THD-v maksimum sebesar 3,43 \% (sesuai standar IEEE) dan THD-i maksimum sebesar 94,86\%. Nilai TDD maksimum 0,73\% (sesuai standar IEEE), namun IHD-i orde ke-5, ke-7, dan ke-11 melebihi standar IEEE, dengan nilai masingmasing 70,04\%, 43,38\%, dan 21,5\%. Pemasangan filter harmonisa di titik pengukuran dari hasil simulasi menggunakan ETAP 12.6.0 menunjukkan hasil yang paling optimum dengan nilai THD-i turun menjadi $0,00 \%$.
\end{abstract}

Kata kunci : Filter harmonisa, gardu traksi, harmonisa, Kereta Rel Listrik (KRL)

\begin{abstract}
The electrification system on the Jabodetabek Electric Train uses a direct current system of 1500 VDC. The 1,500 VDC overhead system is supplied from the traction substation which is equipped with a silicon rectifier component. This rectifier component can produce harmonics that can distort the medium voltage source of $20 \mathrm{kV} \mathrm{PLN}$ and in the long run can cause damage to electrical equipment. This study aims to determine the value of the harmonic voltage and current and to design a harmonic filter on the KRL traction substation. The results of harmonic distortion measurements on $20 \mathrm{kV} / 1.2 \mathrm{kV}$ cubicle at traction substations with PQA show a maximum THD-v of 3.43\% (according to IEEE standards) and a maximum THD-i of 94.86\%. The maximum TDD value is $0.73 \%$ (according to the IEEE standard), but the 5th, 7th and 11th IHD-i exceeds the IEEE standard, with values of 70.04\%, 43.38\%, and 21.5\%. The design of harmonic filters using ETAP 12.6.0 shows the value of THD-i dropped to 0.00\%.
\end{abstract}

Keywords：Electric Train; harmonics; harmonic filters; traction substation

\section{PENDAHULUAN}

Kereta Rel Listrik (KRL) merupakan sarana transportasi masal di JABODETABEK yang paling banyak penggunanya. Dalam operasinya KRL membutuhkan sistem listrik arus searah atau DC. Sehingga perlu adanya gardu traksi yang dilengkapi dengan komponen rectifier untuk mengubah arus bolak-balik AC dari PLN menjadi arus searah DC. Berdasarkan penelitian sebelumnya, penyearah (rectifier) pada gardu traksi adalah penyebab utama distorsi harmonisa pada suplai listrik AC. Total Harmonic Distortion (THD) arus dari sistem, konsumsi daya reaktif, ketidakseimbangan tegangan, masalah flicker dan faktor daya rendah dapat berdampak buruk pada sistem distribusi daya yang merupakan sumber pasokan sistem gardu traksi [1]-[3]. Oleh karena itu perlu dilakukan pengukuran nilai harmonisa pada gardu traksi untuk mengetahui apakah sudah sesuai dengan standar atau melebihi. Jika nilai harmonisa tersebut melebihi standar yang telah ditetapkan, maka salah satu cara untuk mengatasinya yaitu dengan pemasangan filter harmonik. Penelitian ini bertujuan untuk mengukur nilai harmonisa pada gardu traksi KRL serta merancang filter harmonisa untuk memitigasi harmonisa tersebut. Kontribusinya diharapkan dapat menjadi referensi dan tindak lanjut sehingga terjadi peningkatkan efisiensi dan kestabilan sistem di KRL di JABODETABEK.

\section{STUDI PUSTAKA}

\section{A. Sistem Kelistrikan KRL}

Kereta Rel Listrik (KRL) merupakan kereta yang penggerak utamanya menggunakan motor listrik. Catu daya listrik disuplai dari jaringan tegangan menengah $20 \mathrm{kV}$ PLN. Jaringan tegangan menengah ini masuk ke gardu traksi kemudian disalurkan ke KRL menggunakan kawat konduktor yang membentang di bagian atas jalur KRL tersebut yang disebut dengan sistem catenary atau LAA (Listrik Aliran Atas). Sistem elektrifikasi pada kereta rel listrik (KRL) dapat dibagi berdasarkan jenis arus listriknya, yaitu:

1. Arus AC: $15 \mathrm{kV}$ AC $16 \mathrm{~Hz}$ dan $25 \mathrm{kV}$ AC $50 \mathrm{~Hz}$

2. Arus DC: $750 \mathrm{~V} \mathrm{DC}, 1500 \mathrm{~V} \mathrm{DC}, 3000 \mathrm{~V} \mathrm{DC}$

Sistem elektrifikasi pada kereta rel listrik (KRL) di JABODETABEK menggunakan sistem arus searah 1500 Volt DC yang disuplai dari gardu traksi seperti yang dijelaskan pada gambar dibawah ini.

\section{B. Gardu Traksi KRL}

Indonesia pertama kali membangun gardu traksi KRL pada tahun 1925/1926 di Jatinegara dan Ancol dengan menggunakan sistem konfigurasi motor dan generator buatan General Electric. Saat ini, sistem gardu traksi menggunakan teknologi penyearah berbahan silikon. Penyearah (rectifier) pada gardu traksi ini merupakan penyebab utama distorsi 
harmonisa pada suplai listrik AC. Total Harmonic Distortion (THD) arus dari sistem, konsumsi daya reaktif, ketidakseimbangan tegangan, masalah flicker dan faktor daya rendah dapat berdampak buruk pada sistem distribusi daya yang merupakan sumber pasokan sistem gardu traksi [1]-[3].

Selain penyearah, pada gardu traksi terdapat beberapa panel dan komponen diantaranya : panel $20 \mathrm{kV}$, panel $6 \mathrm{kV}$, trafo $20 \mathrm{kV} / 1200 \mathrm{~V}$, trafo $20 \mathrm{kV} / 6 \mathrm{kV}$, trafo $20 \mathrm{kV} / 380 \mathrm{~V}$, trafo $6 \mathrm{kV} / 380 \mathrm{~V}$, Silicon rectifier, DC Switchgear, panel $\mathrm{AC} / \mathrm{DC}$, baterai dan charger, panel interkoneksi, panel VCP, serta panel LBD. Spesifikasi dari setiap komponen berbedabeda tergantung dari daya yang disuplai gardu traksi. Di JABODETABEK, gardu traksi umumnya memiliki daya bervariasi antara $1500 \mathrm{~kW}, 3000 \mathrm{~kW}$, atau $4000 \mathrm{~kW}$.

\section{Harmonisa}

\section{- Definisi}

Harmonisa didefinisikan sebagai penyimpangan bentuk gelombang tegangan dan arus akibat adanya gelombang pendistorsi dengan frekuensi kelipatan dari frekuensi fundamental pada sistem [4]. Hasil dari gelombang yang terdistorsi ini dapat dilihat dengan melakukan superposisi antara gelombang frekuensi fundamental dengan gelombang pendistorsinya. Frekuensi harmonisa dapat dihitung dengan persamaan berikut: [4]

$$
f h=f 1 \times n
$$

dengan:

$\mathrm{fh}=$ frekuensi harmonisa ke-n $[\mathrm{Hz}]$

$\mathrm{f}=$ frekuensi fundamental sistem $[\mathrm{Hz}]$

$\mathrm{n}=$ orde harmonisa

Sehingga dapat disimpulan bahwa harmonisa orde ke-1 merupakan frekuensi fundamentalnya, maka orde ke-1 bukan merupakan harmonisa. Harmonisa dimulai dari orde ke-2 dan seterusnya. Orde harmonisa dapat diperoleh dari representasi dari gelombang yang terdistorsi dengan menggunakan metode Fourier Series. Persamaan Fourier Series adalah sebagai berikut: [4]

dengan :

$$
v(t)=V_{0}+\sum\left(a_{k} \cos (k \omega t)+b_{k} \sin (k \omega t)\right)
$$

$\omega=2 \pi f$

$\mathrm{k}=$ konstanta dengan nilai 1 hingga tak hingga

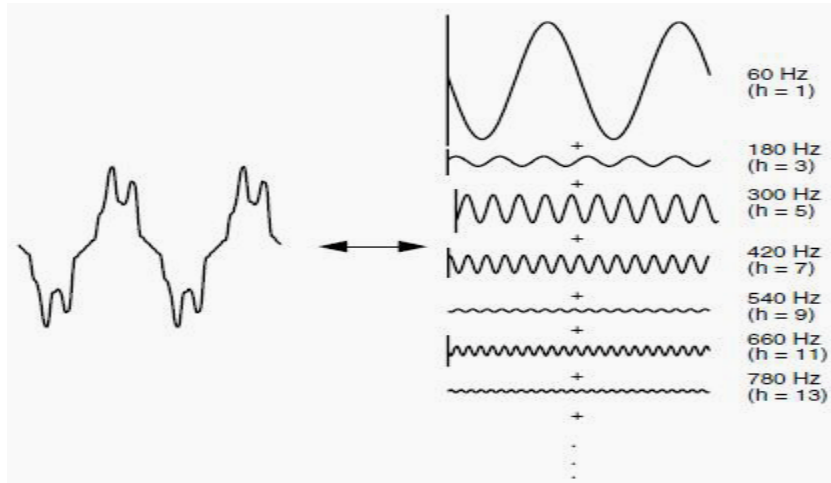

Gambar 1. Representasi Fourier dari gelombang terdistorsi [4]

Harmonisa dapat menyebabkan bentuk gelombang tegangan dan arus menjadi tidak sinusoidal murni. Gelombang pendistorsi ini timbul akibat adanya komponen non-linier pada perangkat dan beban di suatu sistem tenaga listrik. Beban non-linier biasanya berupa komponen semikonduktor yang proses kerjanya betindak seperti saklar yang bekerja pada setiap setengah siklus gelombang, ataupun merupakan beban yang selama bekerja membutuhkan arus yang tidak tetap. Beberapa contoh beban non-linier yaitu rectifier, inverter, lampu fluorescent yang menggunakan ballast elektronik, motor listrik yang kecepatannya dapat diatur, dan lain-lain.

\section{- Penyebab Harmonisa}

Beban non linier merupakan penyebab utama terjadinya harmonisa. Perbandingan antara beban linier dan beban non linier akan menimbulkan adanya beban lebih harmonisa. Apabila dibandingkan dengan beban linier yang memiliki bentuk gelombang tegangan atau arus yang selalu berbentuk sinusoidal dengan frekuensi yang sama, beban non linier akan menyebabkan bentuk gelombang sinusoidal berubah menjadi bentuk yang tidak sinusoidal murni lagi. Beban non linier biasanya berupa komponen semikonduktor yang proses kerjanya berfungsi sebagai saklar yang bekerja pada setiap setengah siklus gelombang. Secara umum sumber harmonisa terdiri dari komponen elektronika daya seperti converter PWM, inverter, rectifier. Harmonisa juga dapat bersumber dari peralatan saturasi seperti trafo, mesin listrik, dan magnetik ballast.

\section{- Akibat yang Ditimbulkan}

Harmonisa dapat membawa tiga pengaruh besar terhadap transformator yang dapat menurunkan kualitas kerja dari transformator yaitu eddy current loss, arus RMS (Root Means Square),dan rugi inti. harmonisa juga dapat menyebabkan kerugian-kerugian lain seperti: Pada panel listrik akan terjadi getaran mekanis yang merupakan getaran resonansi mekanis akibat harmonisa arus dengan frekuensi yang tinggi. Pada KWh meter bertipe elektromekanis yang memakai piringan induksi berputar, harmonisa bisa menyebabkan torsi menjadi bertambah. Efeknya, kecepatan putaran piringan akan menjadi lebih cepat sehingga terjadi kesalahan pengukuran pada $\mathrm{kWh}$ meter dikarenakan piringan induksi ini hanya didesain untuk bekerja pada frekuensi fundamental. Pada pemutus beban dapat menyebabkan operasinya dibawah rating arus pengenalnya atau bahkan bisa juga tidak beroperasi pada arus pengenalnya. Namun, pemutus beban yang memiliki respon terhadap arus rms sebenarnya (true-rms current) atau kenaikan temperatur karena arus lebih dapat terhindar dari gangguan harmonisa tersebut.

\section{- Filter Harmonisa}

Filter harmonisa adalah alat yang berfungsi untuk memperbaiki bentuk gelombang tegangan maupun arus yang terdistorsi oleh harmonisa, sehingga bentuknya akan menjadi menyerupai sinusoidal murni. Prinsip kerja filter harmonisa yaitu dengan cara menurunkan amplitudo satu atau lebih frekuensi tertentu dari sebuah tegangan ataupun arus. Diharapkan dengan adanya pemasangan filter harmonisa pada suatu sistem tenaga listrik yang terdapat sumber-sumber harmonisa di dalamnya, maka penyebaran arus harmonisa ke seluruh jaringan bisa dikurangi sekecil mungkin. Filter harmonisa terbagi menjadi dua jenis yaitu filter pasif dan filter aktif. Filter pasif terdiri dari kombinasi komponen induktor, kapasitor serta resistor. Sedangkan filter aktif disusun dari komponen elektronika daya yaitu MOSFET ataupun IGBT. 
- Standar IEEE Untuk Harmonisa

\begin{tabular}{|c|c|c|}
\hline $\begin{array}{c}\text { Tegangan Bus } \\
(\mathbf{k V})\end{array}$ & $\begin{array}{c}\text { IHD-V } \\
(\boldsymbol{\%})\end{array}$ & $\begin{array}{c}\text { THD.V } \\
(\boldsymbol{\%})\end{array}$ \\
\hline $\mathrm{V}<69$ & 3,0 & 5,0 \\
\hline $69 \leq \mathrm{V}<161$ & 1,5 & 2,5 \\
\hline $\mathrm{V} \geq 161$ & 1,0 & 1,5 \\
\hline
\end{tabular}

Tabel 1. Standar Distorsi Harmonisa Tegangan [5]

\begin{tabular}{|c|c|c|c|c|c|c|}
\hline \multirow{2}{*}{ ISC/IL } & \multicolumn{5}{|c|}{ Orde Harmonik Invidual (Orde ganjil) (\%) } & \multirow{2}{*}{$\begin{array}{l}\text { TDD } \\
(\%)\end{array}$} \\
\hline & $<11$ & $11<\mathrm{n}<17$ & $17<n<23$ & $23<n<35$ & $\mathrm{n}<35$ & \\
\hline$<20$ & 4,0 & 2,0 & 1,5 & 0,6 & 0,3 & 5,0 \\
\hline $20-50$ & 7,0 & 3,5 & 2,5 & 1,0 & 0,5 & 8,0 \\
\hline $50-100$ & 10,0 & 4,5 & 4,0 & 1,5 & 0,7 & 12,0 \\
\hline $100-1000$ & 12,0 & 5,5 & 5,0 & 2,0 & 1,0 & 15,0 \\
\hline$>1000$ & 15,0 & 7,0 & 6,0 & 2,5 & 1,4 & 20,0 \\
\hline \multicolumn{7}{|c|}{ orde genap dibatasi sebesar $25 \%$ dari angka diatas } \\
\hline \multicolumn{7}{|c|}{$\begin{array}{l}\text { dengan: } \\
\text { TDD } \quad=\text { Total Demand Distortion } \\
\text { ISC } \quad=\text { arus hubung singkat maksimum pada PCC } \\
\text { IL } \quad=\text { arus maksimum yang dibutuhkan beban dengan } \\
\text { frekuensi fundamental pada PCC }\end{array}$} \\
\hline
\end{tabular}

Tabel 2. Standar Distorsi Harmonisa Arus [5]

Berdasarkan standar harmonisa IEEE 519-1992, terdapat dua kriteria yang dipakai untuk menentukan standar harmonisa, kriteria yang pertama yaitu batasan untuk distorsi harmonisa tegangan (THD-V) serta yang kedua yaitu batasan untuk distorsi harmonisa arus (TDD). Standar batasan harmonisa tegangan (THD-V) ditentukan oleh nilai tegangan sistem. Pada gardu traksi KRL, penyearah/rectifier disuplai oleh trafo 20/1,2 kV. Sehingga standar THD-V nya adalah tidak melebihi $5 \%$. Sedangkan standar TDD tergantung dari nilai ISC per IL sistem, dimana ISC adalah arus hubung singkat yang terjadi pada Point of Common Coupling (PCC) dan IL adalah arus bebannya.

\section{METODE PENGUKURAN DAN PERANCANGAN FILTER HARMONISA}

\section{A. Metode Pengukuran Harmonisa}

Pengukuran ini bertujun untuk mengetahui nilai distorsi harmonisa pada kubikel yang menyuplai penyearah silicon rectifier. Alat ukur yang digunakan adalah Power Quality Analyzer (PQA). Alat Power Quality Analyzer (PQA) dipasang pada kubikel metering tepatnya pada sisi sekunder transformator arus (CT) dan transformator tegangan (PT). Hal ini dikarenakan keterbatasan rating pengukuran arus dan tegangan alat ukur. Pengukuran dilakukan selama 4 hari (selasa, rabu, kamis dan jum'at) dengan interval pencuplikan data 1 menit. Skema rangkaian pengukuran dapat dilihat seperti pada gambar berikut.

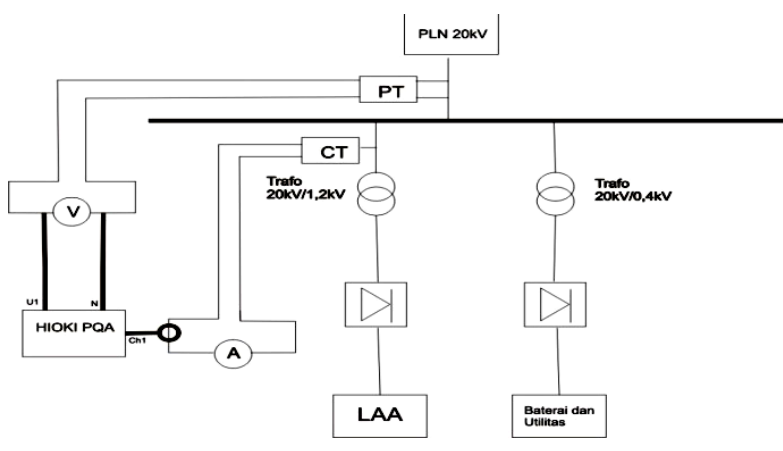

Gambar 2. Rangkaian Pengukuran Kubikel 20kV/1,2kV

\section{B. Perancangan Filter Harmonisa}

Jenis filter yang akan dirancang pada penelitian ini yaitu filter pasif berjenis single tuned. Filter single tuned idealnya hanya akan bekerja mengurangi distorsi harmonisa pada satu orde saja, yaitu pada orde kerjanya. Mengacu pada data hasil pengukuran, orde penyumbang THD-V terbesar yaitu pada orde ke-5 dan orde penyumbang THD-I terbesar yaitu pada orde ke-5, ke-7, dan ke-11. Dikarenakan nilai THD-V masih berada didalam standar IEEE, maka filter dirancang untuk memitigasi THD-I yaitu filter pasif single tuned orde ke-5, orde ke-7, dan ke-11.

Dalam mendesain suatu filter pasif, maka perlu diketahui besarnya parameter-parameter yang dibutuhkan. Parameterparameter tersebut yaitu kompensasi daya reaktif (QVAR), reaktansi kapasitif (Xc), kapasitansi (C), reaktansi induktif (XL), dan induktansi (L). Untuk mencari parameter tersebut dapat mengggunakan persamaan berikut: $[4,6]$

$$
\begin{aligned}
& Q_{V A R}=\sqrt{\left[\frac{P}{P F \text { awal }}\right]^{2}-P^{2}}-\sqrt{\left[\frac{P}{P F \text { akhir }}\right]^{2}-P^{2}} \\
& \mathrm{X}_{\mathrm{C}} \quad=\frac{\mathrm{V}^{2}}{\mathrm{QVAR}} \\
& \text { C }=\frac{1}{2 \pi \mathrm{fXc}} \\
& \mathrm{X}_{\mathrm{L}} \quad=\frac{\mathrm{Xc}}{\mathrm{n}^{2}} \\
& \text { L } \quad=\frac{X L}{2 \pi f}
\end{aligned}
$$

dengan:

$$
\begin{array}{ll}
\mathrm{Q}_{\mathrm{VAR}} & =\text { Kompensasi daya reaktif [kVAR] } \\
\mathrm{P} & =\text { Daya aktif }[\mathrm{kW}] \\
\mathrm{PF} & =\text { Faktor daya } \\
\mathrm{V} & =\text { Tegangan [Volt }] \\
\mathrm{f} & =\text { Frekuensi fundamental }[\mathrm{Hz}] \\
\mathrm{Xc} & =\text { Reaktansi kapasitif }[\Omega] \\
\mathrm{C} & =\text { Kapasitansi }[\boldsymbol{\mu F}] \\
\mathrm{X}_{\mathrm{L}} & =\text { Reaktansi induktif }[\Omega] \\
\mathrm{L} & =\text { Induktansi }[\mathrm{mH}]
\end{array}
$$




\section{HASIL PENGUKURAN PADA GARDU TRAKSI} DAN SIMULASI PADA ETAP 12.6.0

\section{A. Data Hasil Pengukuran Harmonisa}

- Harmonisa Tegangan

Tabel 3. Hasil Pengukuran Harmonisa Tegangan

\begin{tabular}{|c|c|c|c|c|}
\hline \multirow{3}{*}{ Hari } & \multirow{3}{*}{ Fasa } & \multicolumn{3}{|c|}{ THD-V } \\
\hline & & \multicolumn{2}{|c|}{ Maksimum } & \multirow{2}{*}{ Rata-rata $(\%)$} \\
\hline & & Nilai $(\%)$ & Waktu & \\
\hline \multirow{3}{*}{ Selasa } & $\mathrm{R}$ & 2,85 & 04.32 & 2,08 \\
\hline & S & 2,7 & 04.32 & 1,96 \\
\hline & $\mathrm{T}$ & 2,77 & 04.32 & 1,93 \\
\hline \multirow{3}{*}{ Rabu } & $\mathrm{R}$ & 3,2 & 21.28 & 1,92 \\
\hline & S & 3,22 & 12.28 & 1,93 \\
\hline & $\mathrm{T}$ & 3,18 & 12.28 & 1,91 \\
\hline \multirow{3}{*}{ Kamis } & $\mathrm{R}$ & 3,22 & 21.05 & 2 \\
\hline & $\mathrm{S}$ & 3,15 & 21.05 & 1,92 \\
\hline & $\mathrm{T}$ & 3,27 & 21.05 & 1,96 \\
\hline \multirow{3}{*}{ Jum'at } & $\mathbf{R}$ & 3,47 & 13.58 & 2,41 \\
\hline & $\mathrm{S}$ & 3,43 & 10.44 & 2,09 \\
\hline & $\mathrm{T}$ & 3,4 & 10.44 & 2,09 \\
\hline
\end{tabular}

- Harmonisa Arus

Tabel 4. Hasil Pengukuran Harmonisa Arus

\begin{tabular}{|c|c|c|c|c|}
\hline \multirow{3}{*}{ Hari } & \multirow{3}{*}{ Fasa } & \multicolumn{3}{|c|}{ THD-I } \\
\hline & & \multicolumn{2}{|c|}{ Maksimum } & \multirow{2}{*}{ Rata-rata $(\%)$} \\
\hline & & Nilai (\%) & Waktu & \\
\hline \multirow{3}{*}{ Selasa } & $\mathrm{R}$ & 88,04 & 02.21 & 50,29 \\
\hline & $\mathrm{S}$ & 91,28 & 02.21 & 49,01 \\
\hline & $\mathbf{T}$ & 94,86 & 02.21 & 44,86 \\
\hline \multirow{3}{*}{ Rabu } & $\mathrm{R}$ & 84,94 & 05.08 & 32,72 \\
\hline & $\mathrm{S}$ & 90,04 & 05.08 & 32,22 \\
\hline & $\mathrm{T}$ & 79,83 & 05.08 & 31,73 \\
\hline \multirow{3}{*}{ Kamis } & $\mathrm{R}$ & 86,7 & 01.48 & 33,83 \\
\hline & S & 90,54 & 05.38 & 33,07 \\
\hline & $\mathrm{T}$ & 80,21 & 01.48 & 32,09 \\
\hline \multirow{3}{*}{ Jum'at } & $\mathrm{R}$ & 84,85 & 01.21 & 39,7 \\
\hline & $\mathrm{S}$ & 87,71 & 04.58 & 38,71 \\
\hline & $\mathrm{T}$ & 81,14 & 04.58 & 35,04 \\
\hline
\end{tabular}

- Konsumsi Daya

Tabel 5. Hasil Pengukuran Konsumsi Daya

\begin{tabular}{|c|c|c|c|c|}
\hline Hari & Nilai & $\mathrm{P}(\mathrm{kW})$ & $\mathrm{Q}(\mathrm{kVAR})$ & $\mathrm{S}(\mathrm{kVA})$ \\
\hline \multirow{2}{*}{ Selasa } & Maksimum & 2899 & 683 & 3031 \\
\cline { 2 - 5 } & Minimum & 7 & -10 & 12 \\
\hline
\end{tabular}

\begin{tabular}{|c|c|c|c|c|} 
& Rata-rata & 678 & 56 & 688 \\
\hline Hari & Nilai & $\mathrm{P}(\mathrm{kW})$ & $\mathrm{Q}(\mathrm{kVAR})$ & $\mathrm{S}(\mathrm{kVA})$ \\
\hline \multirow{4}{*}{ Rabu } & Maksimum & $\mathbf{3 6 0 7}$ & $\mathbf{1 2 3 1}$ & $\mathbf{3 8 1 1}$ \\
\cline { 2 - 5 } & Minimum & 7 & -10 & 12 \\
\cline { 2 - 5 } & Rata-rata & 660 & 106 & 671 \\
\hline \multirow{4}{*}{ Kamis } & Maksimum & 2932 & 880 & 3061 \\
\cline { 2 - 5 } & Minimum & 6 & -10 & 11 \\
\cline { 2 - 5 } & Rata-rata & 560 & 86 & 568 \\
\hline \multirow{3}{*}{ Jum'at } & Maksimum & 2930 & 890 & 3241,5 \\
\cline { 2 - 5 } & Minimum & 6 & -10 & 11,5 \\
\cline { 2 - 5 } & Rata-rata & 597 & 72 & 633 \\
\hline
\end{tabular}

\section{B. Analisis Data Hasil Pengukuran}

\section{- Harmonisa Tegangan}

Berdasarkan tabel 3, terlihat bahwa nilai THD-V maksimum terjadi pada waktu dan fasa yang berbeda-beda setiap harinya. Hal tersebut terjadi karena beban keretanya juga berubah-ubah setiap harinya. Diperoleh nilai maksimum THD-V terjadi pada hari Jum'at pada fasa R sebesar 3,47\%. Adapun tiga orde penyumbang harmonisa tegangan terbesar ketika terjadinya nilai maksimum THD-V yaitu orde ke-5 sebesar 3,28\%; orde ke-11 sebesar 0,61\%; dan orde ke-7 sebesar $0,5 \%$. Biasanya, pada orde ganjil akan memiliki nilai yang lebih besar dibandingkan dengan orde genap, hal tersebut terjadi dikarenakan pada gelombang yang mempunyai orde genap ataupun yang mempunyai frekuensi yang merupakan kelipatan genap dari frekuensi fundamentalnya, cenderung akan saling menghilangkan satu sama lain sehingga pengaruhnya tidaklah terlalu besar [4]. Untuk lebih lengkap mengenai kesesuaian nilai THD-V dengan standar IEEE ditampilkan pada tabel 6 berikut.

Tabel 6. Penyesuaian THD-V dengan standar IEE 519-1992

\begin{tabular}{|c|c|c|c|}
\hline Hari & Fasa & THD-V (\%) & Sesuai \\
\hline Selasa & $\mathrm{R}$ & 2,85 & Ya \\
\hline Rabu & $\mathrm{S}$ & 3,22 & Ya \\
\hline Kamis & $\mathrm{T}$ & 3,27 & Ya \\
\hline Jum'at & $\mathrm{R}$ & 3,47 & Ya \\
\hline
\end{tabular}

\section{- Harmonisa Arus}

Berdasarkan tabel 4 diatas, terlihat bahwa nilai THD-I maksimum berfluktuasi setiap harinya. Waktu terjadinya THD-I maksimum mayoritas terjadi saat dini hari ketika kereta sedang tidak beroperasi, melainkan sedang dilakukan perawatan dan juga starting motor. Diperoleh nilai THD-I maksimum terjadi pada hari Selasa pada fasa $\mathrm{T}$ sebesar $94,86 \%$. Untuk lebih lengkap, tabel 3.5 berikut akan menunjukkan nilai harmonisa arus pada setiap orde ketika terjadinya nilai maksimum THD-I. Orde penyumbang harmonisa arus terbesar yaitu orde ke-5 sebesar 70,04\%, orde ke-7 sebesar 43,38\%, dan orde ke-11 sebesar 21,5\%. Hal tersebut identik dengan harmonisa tegangan, dimana 3 orde penyumbang harmonisa terbesar adalah orde ke-5, orde ke-7, dan orde ke-11. Harmonisa pada orde ganjil akan memiliki nilai yang lebih besar dibandingkan dengan orde genap, hal 
tersebut terjadi dikarenakan pada gelombang orde genap ataupun yang frekuensinya yang merupakan kelipatan genap dari frekuensi fundamentalnya, cenderung akan saling menghilangkan satu sama lain sehingga pengaruhnya tidak signifikan [4].

Untuk mengetahui kesesuaian data hasil pengukuran harmonisa arus dengan standar yang ada maka perlu dihitung terlebih dahulu nilai ISC/IL nya. Dengan menggunakan ETAP diperoleh nilai Isc $=577 \mathrm{~A}$ dan $\mathrm{IL}=118 \mathrm{~A}$, maka nilai $\mathrm{ISC} / \mathrm{IL}=4,89$. Sehingga pada gardu traksi KRL nilai maksimum TDD-I adalah sebesar 5,0\%.

$$
\operatorname{TDD}(\%)=\frac{\sqrt{\sum_{\mathrm{n}=2}^{\mathrm{nmaks}} \mathrm{In}^{2}}}{\mathrm{IL}} \times 100 \%
$$

Tabel 7. Penyesuaian Harmonisa Arus dengan Standar IEE 519-1992

\begin{tabular}{|c|c|c|c|}
\hline Hari & Parameter & $(\boldsymbol{\%})$ & Sesuai \\
\hline \multirow{4}{*}{ Selasa } & TDD & 0,68 & Ya \\
\cline { 2 - 4 } & IHD-i orde 5 & 70,04 & Tidak \\
\cline { 2 - 4 } & IHD-I orde 7 & 43,38 & Tidak \\
\cline { 2 - 4 } & IHD-i orde 11 & 21,5 & Tidak \\
\hline \multirow{4}{*}{ Rabu } & TDD & 0,71 & Ya \\
\cline { 2 - 4 } & IHD-i orde 5 & 65,38 & Tidak \\
\cline { 2 - 4 } & IHD-I orde 7 & 43,1 & Tidak \\
\cline { 2 - 4 } & IHD-i orde 11 & 18,95 & Tidak \\
\hline \multirow{4}{*}{ Kamis } & TDD & 0,71 & Ya \\
\cline { 2 - 4 } & IHD-i orde 5 & 67,01 & Tidak \\
\cline { 2 - 4 } & IHD-I orde 7 & 40,23 & Tidak \\
\cline { 2 - 4 } & IHD-i orde 11 & 21,4 & Tidak \\
\hline \multirow{4}{*}{ Jum'at } & TDD & 0,73 & Ya \\
\cline { 2 - 4 } & IHD-i orde 5 & 63,88 & Tidak \\
\cline { 2 - 4 } & IHD-I orde 7 & 42,77 & Tidak \\
\cline { 2 - 4 } & IHD-i orde 11 & 20,67 & Tidak \\
\hline
\end{tabular}

Berdasarkan tabel 6 diatas, maka dapat disimpulkan bahwa nilai TDD masih sesuai dengan standar. Namun nilai IHD-I pada orde ke-5, ke-7, dan ke-11 hasil pengukuran pada gardu traksi KRL tidak sesuai dengan standar IEEE 519-1992. Sehingga diperlukan upaya mitigasi untuk memperbaiki distorsi harmonisa arus tersebut.

\section{Simulasi pada ETAP 12.6.0}

\section{- Spesifikasi Filter}

Spesifikasi filter dihitung berdasarkan profil daya hari Rabu yang merupakan pemakaian daya maksimum selama 4 hari pengukuran. Berdasarkan persamaan (3)-(7), diperoleh spesifikasi filter single tuned untuk orde ke-5, orde ke-7, dan orde ke-11 adalah seperti yang ditampilkan pada tabel 8 berikut.

Tabel 8. Spesifikasi Filter

\begin{tabular}{|l|c|c|c|c|c|}
\hline Orde & Q kVAR & $\begin{array}{c}\text { XC } \\
(\mathbf{o h m})\end{array}$ & $\mathbf{C}(\mathbf{u F})$ & $\begin{array}{c}\mathbf{X L} \\
(\mathbf{o h m})\end{array}$ & $\mathbf{L}(\mathbf{m H})$ \\
\hline $\mathrm{Ke}-5$ & 577 & 2,49 & 1279 & 0,104 & 0,33 \\
\hline
\end{tabular}

\begin{tabular}{|l|l|l|c|c|}
\hline Ke-7 & & & 0,053 & 0,17 \\
\hline Ke-11 & & & 0,02 & 0,064 \\
\hline
\end{tabular}

\section{- Hasil Simulasi}

Simulasi pada perangkat lunak ETAP 12.6.0 dilakukan sebanyak tiga kali yaitu simulasi sebelum pemasangan filter, simulasi pemasangan filter didekat rectifier, dan simulasi pemasangan filter di titik pengukuran. Tabel 9 berikut ini merupakan hasil simulasinya.

Tabel 9. Hasil Simulasi

\begin{tabular}{|c|c|c|c|}
\hline \multirow{2}{*}{$\begin{array}{c}\text { Orde } \\
\text { ke- }\end{array}$} & $\begin{array}{c}\text { Sebelum } \\
\text { dipasang filter }\end{array}$ & $\begin{array}{c}\text { Filter dipasang } \\
\text { di dekat rectifier }\end{array}$ & $\begin{array}{c}\text { Filter dipasang } \\
\text { di titik } \\
\text { pengukuran }\end{array}$ \\
\hline 5 & 55,4 & 2,1 & 0,003 \\
\hline 7 & 43,9 & 0,7 & 0,0001 \\
\hline 11 & 32 & 0,3 & 0,00026 \\
\hline Total & 52,81 & 2,73 & 0,00 \\
\hline
\end{tabular}

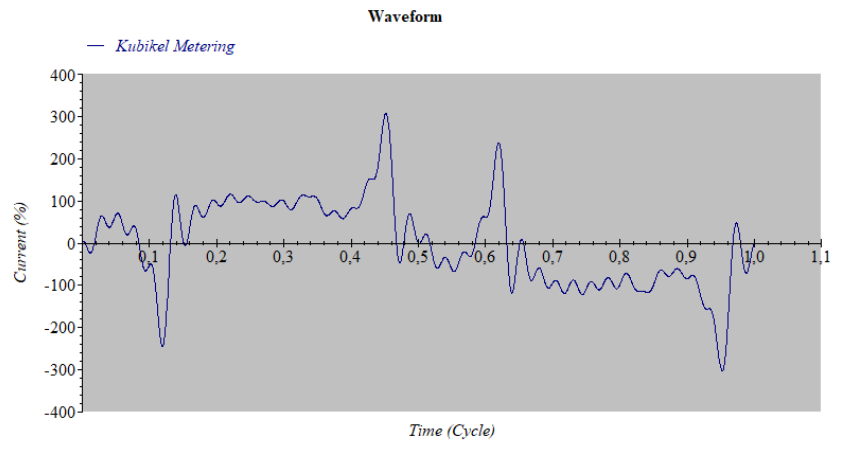

Gambar 2. Bentuk gelombang sebelum pemasangan filter Waveform

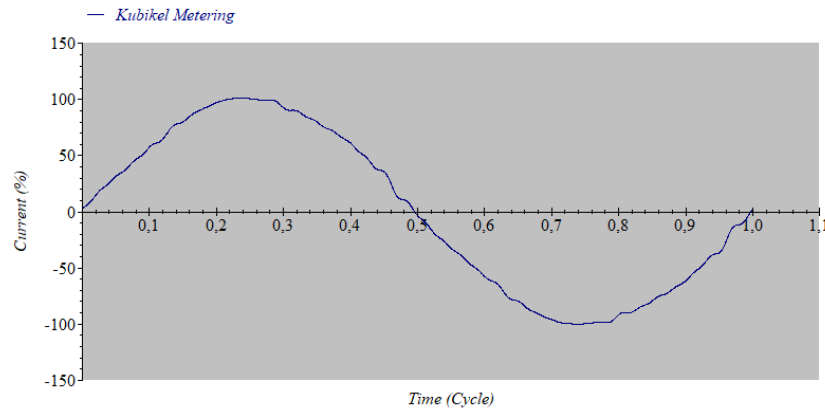

Gambar 3. Bentuk gelombang setelah pemasangan filter di dekat rectifier 


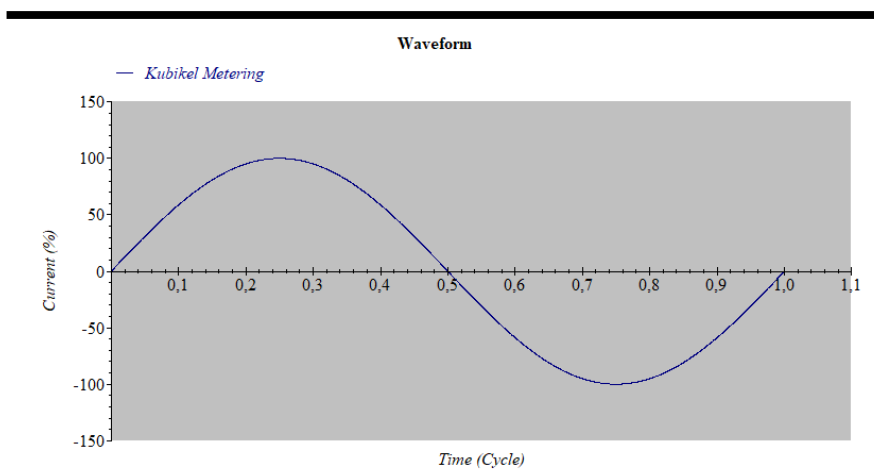

Gambar 4. Bentuk gelombang setelah pemasangan filter di titik pengukuran

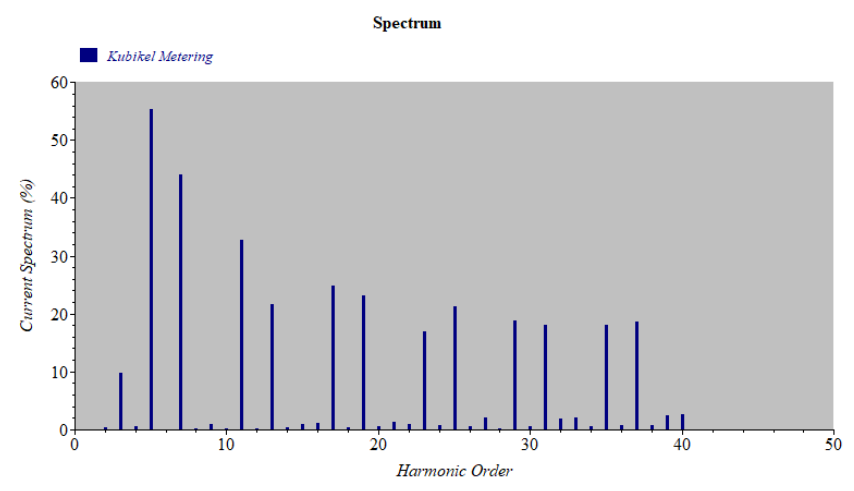

Gambar 5. Spektrum IHD-i sebelum pemasangan filter

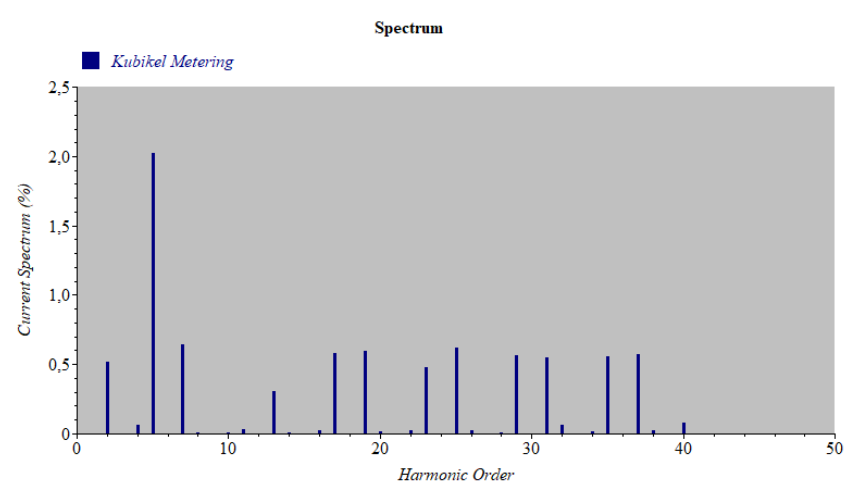

Gambar 6. Spektrum IHD-i setelah pemasangan filter di dekat rectifier

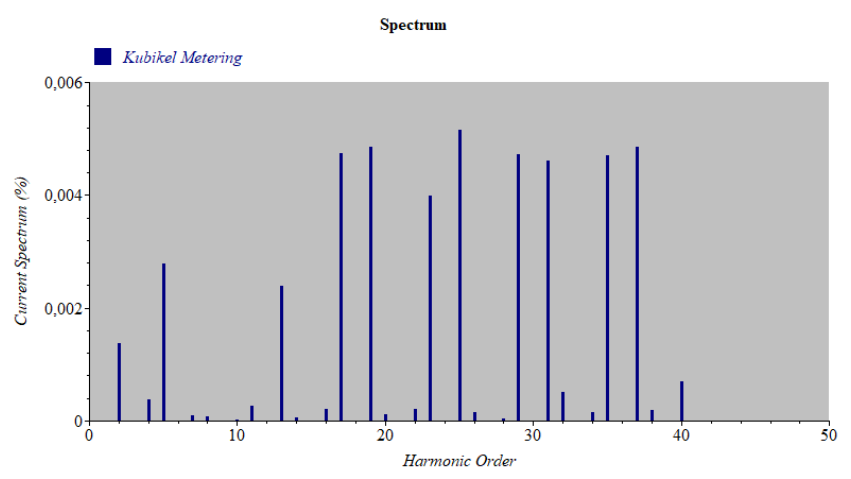

Gambar 7. Spektrum IHD-i setelah pemasangan filter di titik pengukuran
Setelah dilakukan tiga kali simulasi pada perangkat lunak ETAP 12.6.0 yaitu simulasi sebelum pemasangan filter, simulasi pemasangan filter di dekat penyearah / rectifier, dan simulasi pemasangan filter di titik pengukuran, diperoleh beberapa data. Berdasarkan gambar 2, 3, dan 4, terlihat bahwa sebelum pemasangan filter bentuk gelombang arus sangat berantakan. Setelah dilakukan pemasangan filter di dekat penyearah / rectifier, bentuk gelombang sudah sinusoidal namun masih terdapat sedikit riak. Kemudian setelah filter dipindah dan dipasang di titik pengukuran, bentuk gelombangnya semakin halus. Nilai THD-I nya adalah sebesar $0,001 \%$, namun bila dilihat dari spektrum sebenarnya masih tersisa sedikit harmonisa pada beberapa orde dengan nilai dibawah $0,005 \%$ atau sangat kecil sekali. Tentu saja nilai tersebut sudah sesuai dengan standar IEEE 519-1992. Sehingga dapat disimpulkan bahwa dengan spesifikasi filter yang sama, performa filter yang dipasang pada titik pengukuran jauh lebih optimal bila dibandingkan dengan yang dipasang di dekat rectifier. Karena filter yang dipasang pada lokasi ini selain dapat mereduksi harmonisa akibat penyearah / rectifier juga dapat mereduksi harmonisa yang disebabkan oleh charger baterai.

\section{KESIMPULAN}

Distorsi harmonisa tegangan pada gardu traksi KRL sudah sesuai dengan standar IEEE dengan nilai THD-v maksimum $3,47 \%$. Begitu pula dengan harmonisa arus sudah sesuai dengan standar IEE dengan nilai TDD maksimum 0,73\%. Namun nilai IHD-I orde ke-5, orde ke 7, dan orde ke 11 melebihi standar IEEE. Orde penyumbang harmonisa tegangan terbesar adalah orde ke-5, sedangkan orde penyumbang harmonisa arus terbesar adalah orde ke-5, orde ke-7 serta orde ke-11. Berdasarkan hasil simulasi dengan menggunakan ETAP 12.6.0, pemasangan filter single tuned orde ke-5, orde ke-7 dan orde ke-11 pada titik pengukuran yang dirancang berdasarkan profil daya maksimum dapat mengurangi harmonisa arus THD-I menjadi sebesar $0,00 \%$.

\section{REFERENCES}

[1] A. Ogunsola, A. Mariscotti, and L. Sandrolini, "Measurement of AC side harmonics of a DC metro railway," in Electrical Systems for Aircraft, Railway and Ship Propulsion, ESARS, 2012.

[2] P. Pinato and D. Zaninelli, "Harmonic Disturbances in Electric Traction System Overhead Lines," in Proc. International Conference on Harmonics and Quality of Power, 2002, vol. 2, pp. 748-753.

[3] M. Fracchia, A. Mariscotti, R. E. Morrison, and L. Pierrat, "Statistical Analysis of the measured harmonics disturbance on the ac side of a metrorail supply system," in Proc. International Conference on Harmonics and Quality of Power, 1998, vol. 2, pp. 1229-1234.

[4] Dugan, Roger.C and McGranaghan, Mark.F. Electrical Power Systems Quality. New York : McGraw-Hill. 2004.

[5] IEEE 519-1992.

[6] F. Husnayain, N. D. Purnomo, R. Anwar and I. Garniwa, "Harmonics mitigation for offshore platform using active filter and line reactor methods," 2014 International Conference on Electrical Engineering and Computer Science (ICEECS), Kuta, 2014, pp. 331-336, doi: 10.1109/ICEECS.2014.7045272.

- Analisis Hasil Simulasi 